\title{
STREET RAILWAY LAND AND RAILROAD COM-* MISSIONERS IN CONNECTICUT
}

A sketch of the street railway laws of Connecticut, I apprehend will not interest many readers of the Journal outside of this State. At the same time, the subject is not uninteresting from the historical standpoint. Existing legislation is the result of conflict in successive general assemblies between street railway companies and municipalities, and the statutes, as we have them, are in many respects very vague and uncertain.

To-day, in Connecticut, the street railway business is for the most part a monopoly and is associated and practically merged with the corporation doing a steam transportation railroad business.

This merger is under late legislative authority, and no questions have yet arisen concerning the status of the combined, united or separate franchises.

Originally, most of the street railway lines were horse car companies; their charters differed, but can be roughly divided into two classes:

r. Those which had as territory the streets of a city, subject. so far as particular extensions were concerned, to the consent of the municipal authorities.

2. Those-and they constituted by far the larger class-which had defined charter routes.

Some of these old horse car companies changed their motive power to electricity by municipal permission to which conditions were annexed by the municipal councils. Others awaited the passage of the general law of 1893 which permitted a change of motive power to electricity.

The franchises of the latter are freer from entanglements from the owners' viewpoint. How far the strings binding the former's franchises have been loosened by general legislation is by no means settled. By amendments, all charters have become subject to the general street railway law.

The charter of the Consolidated Railway Company was passed by the General Assembly of 1905 . Its owners assert that practically all power has been given to it among men. Municipalities and the public generally dissent from that view, but in all matters 
concerning street railways, either under general laws or special laws, the Railroad Commissioners are the bulwark upon whom the public must lean when a strife between conflicting interests comes.

The Consolidated Railway Compasy was originally the Thompson Tramway Company, incorporated in xgor. Its capital stock was $\$ 50,000$; it could transport persons and property as a common carrier upon the highways and elsewhere in the town of Thompson; could construct, maintain and operate a railway with single or double tracks upon the surface of any highways within the town of Thompson or upon private property in the town; it could take lands within the town for railroad purposes; it could mortgage, sell or lease the whole or any part of its property, including franchises; it could purchase, hold and enjoy stock, assets, property, leases or franchises of any other corporation; could merge, consolidate, and make common stock with other corporations under the name of either of them, and with all the powers of the corporations merged or consolidated.

The Thompson-Tramway Company had acquired prior to Igo5 twenty-three different street railway companies. It obtained in $x$ g05 the right to lay out, construct and operate a railway on routes, the description of which covers four and one-half pages of the public laws. It obtained the right to

make traffic agreements with any railroad company or street railway company, and shall have the right and power, with the consent of any railroad company or street railway company, to construct and maintain connections at grade of its tracks with any tracks of such railroad company or street railway company, and crossovers upon private land at grade for the purpose of making such connections.

It can also acquire and develop water powers for the generation of electricity, and transmit the same, whether developed by steam or water power, to any part of its railroads or railways where electricity is to be used or applied.

It can acquire by lease, purchase or otherwise, and can hold, use, enjoy and dispose of, in whole or in part, the capital stock, evidences of indebtedness, contracts, property, rights, powers, privileges and franchises of any other corporation, of Connecticut or any other State, now or hereafter existing, which are or shall be engaged or authorized to engage in the transportation business or in the development of electricity. It was expressly stated in this charter that

every franchise, right, power or privilege heretofore, now, or hereafter granted to or purchased by the corporation whose charter is herein amended, shall be held, enjoyed, and exercised by said corporation without suffering 
qualification or abatement by construction because of its also holding by grant or purchase other franchises, powers, or privileges of a similar nature, but of a more limited, qualified, or conditional character.

It can condemn minority stock if it owns seventy-five per cent of any other corporation in which it is interested; it can guarantee contracts, bonds and obligations of any other corporation now, hereafter, or whenever organized, which does or can do a transportation business, or which does or can generate or develop electricity or other power; it can likewise guarantee the bonds and securities of any corporation, association or partnership, now, hereafter, or whenever organized, which owns or controls at least a majority of the capital stock of such transportation or electric company.

"The corporation ********** shall for the sake of the convenience of the public, have the right to take, with the approval of the Railroad Commissioners, in the manner provided in section 3687 of the general statutes, real estate, including lands and interest in lands, rights of flowage, and easements of any nature, for the purpose of constructing or improving any railroad or railway which it shall have the authority or right to construct or operate, or for the purpose of developing any water power or transmitting electricity.

The corporation is given authority。

as a matter of public convenience, subject to all general Iaws governing the construction of railways in streets or highways, to locate, construct, maintain and operate railroads, railways or tramways for the transportation of passengers or goods, or both, with single or double tracks, and such turnouts and switches and connections and fixtures and appurtenances as may be necessary for the most efficient, economical and advantageous conduct of said business upon the streets, highways, and public grounds upon which said corporation now operates or shall hereafter lawfully operate, a railroad, railway or tramway; and upon any private lands and across intersecting streets or highways in any of the towns within whach said company shall lawfully operate an electric railway.

It is claimed by the owners of the Consolidated Railway Company charter that it can locate and construct and operate a railroad over any highway in any town in which it operates a street railway under its own or another company's franchise; that it can take private lands in any such towns; that it can make connections in any such towns over private lands between its street railway and steam railroad tracks. As a steam road can use electricity for motive power in Connecticut, it asserts that it can run electric transportation facilities practically anywhere in the State, bisecting whatever property or estate lies in its course.

It has been claimed by the owners of the Consolidated Railway Company franchise that the approval of the railroad commissioners was not necessary to the condemnation of private property, but that the vote of the board of directors of the Consolidated 
Railway Company was sufficient to enable it to go directly to court; that the General Assembly had delegated to such directors the sovereign power of the State to appropriate any lands which they might think necessary for the improvement of street railway facilities.

This claim, however, I understand, has been abandoned, and the approval of the Railroad Commissioners is now admitted by the Consolidated Railway Company to be a sine qua non for taking land or an easement therein.

Let us assume for a moment that these claims are all well founded.

Then the transportation monopoly of Connecticut can, speaking broadly, run an electric railway anywhere across every acre of land in the State. It can run electric cars on steam tracks and carry goods or passengers therein on such tracks by any motive power it sees fit to adopt. It cannot make connections with steam tracks at highways, for that might make a grade crossing forbidden by the general law. It can change the location of its tracks and add tracks, carry its own wires anywhere on the highways and over any private right of way it may purchase. It cannot as yet condemn a right of way for a feed wire, in all probability.

These are the broad claims of the owners of the monopoly. It will be seen that in carrying them out in detail, matters of seemingly trivial importance at first thought, become exceedingly important. The location of double tracks in place of a single line, the location and use of switches, the occupation of cross streets which have been heretofore been regarded as residence streets pure and simple, all at the will of a private corporation-may create burdens which are impossible for the abutting property owners, individually and collectively, to bear. It may come that the old rule that an electric railway line is not an additional highway servitude must be abrogated by the legislature, if not by the courts. I do not mean to be understood as saying that these broad claims under existing franchise grants must be admitted.

Let us assume, however, that they are well founded. Is it strange, in view of the fact that the railroad commissioners seem apparently the only protection between private property and the grasp of the transportation monopoly, that there should be distrust in some quarters of the powers of resistance of the individual members of the Board of Railroad Commissioners?

Up to the present time, this fear is entirely unfounded. The railroad commissioners have been fully alive to the tremendous 
responsibilities placed upon them. Indeed, they cannot afford to weaken, for should they let themselves be overpersuaded in any particular case to approve the request of the monopoly for a privilege to which it is not fairly entitled, the next session of the General Assembly would see the entire monopolistic structure swept from the statute books.

It is for this reason that the monopoly has been very careful in refraining from a quarrel with private persons or municipal authorities, but it needs only the discharge of the first gun of the conflict to revolutionize the policy of the State in dealing with steam railroad and street railway matters.

Railroad commissioners do not act judicially, and their action can be reversed by the General Assembly. State v. $N . H$. o $N$. Co., 43 Conn. $3^{81}$.

Has the State any other protection against the transportation monopoly created by itself than the Board of Railroad Commissioners? In other words, can there be an appeal from their decisions to the courts?

In the case of Spencer's Appeal, 78 Conn. 301 , it was held that the best method of eliminating a grade crossing in a given case was an administrative question pure and simple, and that a statute permitting appeal from an order of the Board of Railroad Commissioners thereon was void.

What questions can come before the Board of Railroad Commissioners that are clearly not administrative? Of course, a decision by the Board relative to the construction of its own powers or the meaning and scope of a legislative grant is on a judicial matter and is subject to appeal. Orders on important matters connected with the exercise by the Consolidated Railway Company of its franchises may also be subject of appeal and are later referred to.

When a right to locate a road is clearly given by charter, but the particular location is subject to the approval of the Board of Railroad Commissioners, its approval fixes the location and is not subject to appeal. $N . H$. \& $N . R . R . C o, v . B . H . \& E . R . R$. Co., $3^{6}$ Conn. $201 ; N . Y . N . H . \& H . R . R$. Co., v. Long, 69 Conn. 424 .

The language of the charter of the Consolidated Railway Company, "the corporation shall for the sake of the convenience of the public have the right to take, with the approval of the Railroad Commissioners," which was designed to give the company an omnibus location, cuts both ways. It was designed, of course, to support a claim that the legislature had found any location 
which the Company might adopt, subject to the approval of the railroad commissioners, to be required by public convenience and necessity. Such a claim, however, seems much too broad, and the clear meaning of the grant is, undoubtedly, that the approval of the Railroad Commissioners can be given only on a finding by that body of public convenience and necessity. Such finding is clearly a judicial act (In re Application of Shelton Street Railway Co., ${ }_{69}$ Conn. 626) and therefore subject to an appeai to the Superior Court. It is possible, however, that the courts might say that the finding of public convenience and necessity was of a fact by a board qualified to find it, and therefore not subject to review by the courts. See 69 Conn. 630 .

Let us assume, then, for the sake of argument, that we have reached in Connecticut, little by little, a place where the power of giving vitality to franchises, of protecting the public from their arbitrary exercise, rests in three men nominated by the Governor and confirmed by the Senate. This Board between sessions of the General Assembly is vested with much of the power of that body.

It is novel in Connecticut, but is such a situation much to be deplored? The days have long since passed, it seems to me, when franchises in matter of detail should be at the whim of a General Assembly. No lawyer who has practiced before legislative committees can fail to be chagrined by the futility of his best efforts, either in draughtsmanship or argument. It is not the fault of the legislature. The pressure on the chairmen of committees, their small preparation for matters submitted to them, the prejudice and ignorance of the rank and file of members of the General Assembly, make a session's work of little avail.

The work of special commissions who study the subjects committed to them is slow, but valuable. If the commission is standing and has the benefit of practical as well as theoretical training, so much the better. After all, it is mainly a matter of the personnel of the commission. In the execution of their orders in railway matters, so much time must necessarily be consumed, that a General Assembly can convene before an order of the Railroad Commissioners on a matter of anything, more than the slightest moment can be effectual. In the legislature lies the power of veto, a reversal of policy or ruling.

This is not to be understood as an assertion that the railroad commissioners of Connecticut as an arm of the State are a perfect body in respect to the scope or limitation of their powers. Far from it. Their inquisitorial powers ought to be enlarged. In 
addition to their duties in respect to the safety of lives; they should be vested with duties in respect to the safety of pocketbooks. The public should have the right to look to them for approval or disapproval of financial plans. Today, the stockholder's meeting can effect the stockmarket, and that is all. It has no authority as to railroad policy, industrial or financial. The statutes in respect to the Railroad Commissioners should be re-written; their salaries should be increased; their clerical and statistical force should be enlarged. The lines separating and defining municipal and State powers as to street railways should be sharpened and made more definite.

But the Railroad Commissioners have immense responsibility under existing legislation. Their arms should be sustained. They should be encouraged to seek more extended jurisdiction.

A General Assembly, when the issue on a railroad question lies in small compass, can be depended on, in general, to decide it rightly; but, what knowledge have its members, or opportunity to know, of railroad matters in general? A chairman can be driven to his seat in confusion by an inquiry, untimely for him, from the back row. He loses the House, and the resulting legislation is unsatisfactory, to say the least.

If the effect of this paper is to inspire some qualified person or persons to undertake the study of a wholesale revision and redraft of Connecticut street railway law, its purpose will not entirely fail. Arthur L. Shipman. 